\title{
A VASALÓERŐ ÁTLAGOS FELÜLETI ÉRDESSÉGRE GYAKOROLT HATÁSÁNAK MODELLEZÉSE
}

\author{
Ferencsik Viktória \\ egyetemi tanársegéd, Miskolci Egyetem, Gyártástudományi Intézet \\ 3515 Miskolc, Miskolc-Egyetemváros, e-mail: ferencsik.viktoria@uni-miskolc.hu
}

\section{Gál Viktor}

tudományos segédmunkatárs, Miskolci Egyetem

Korszerü Anyagok és Intelligens Technológiák Felsőoktatási és Ipari Együttmüködési Központ

3515 Miskolc, Miskolc-Egyetemváros, e-mail: gal.viktor@uni-miskolc.hu

\begin{abstract}
Absztrakt
Egy gépelem kifáradás elleni ellenállása annál nagyobb, minél kevesebb makroszerkezeti változást és belső inhomogenitást tartalmaz. Élettartam szempontjából meghatározó továbbá a kedvező a feszültségállapot és a kisebb felületi érdessége is. Publikációnk az érdességet hatékonyan csökkentö vasalási megmunkálás során beállitott erő átlagos felületi érdességre gyakorolt hatásával, illetve annak végeselemes modellezésével foglalkozik. A folyamat szimulációja DEFORM-2D szoftver alkalmazásával készül, megfelelve a gyakorlatban megvalósitott vasalási paraméterek (vasalási erö, elötolás, sebessé) számszerü értékeinek is, ezáltal lehetövé téve egy összehasonlitó elemzést gyengén ötvözött alumínium anyagminöség esetén.
\end{abstract}

Kulcsszavak: VEM, hideg képlékeny alakitás, átlagos felületi érdesség, DEFORM-2D

\begin{abstract}
The better fatigue resistance for a machine part can be achieved with the less macrostructural changes and inhomogeneities. In addition, the more favourable stress condition and the smaller surface roughness are decisive in terms of service life. Our publication deals with the finite element modeling of the effect of burnishing force on the average surface roughness during burnishing process which effectively reduces roughness. The method is simulated using DEFORM-2D software, corresponding to the numerical values of burnishing parameters (force, speed, feed rate) implemented in practice as well, thereby allowing a comparative analysis in the case of low alloyed aluminium as well.
\end{abstract}

Keywords: FEM, cold plastic forming, average surface roughness, DEFORM-2D

\section{Bevezetés}

A korszerü képlékeny alakítás fő törekvése az, hogy a tervezett alkatrész alakját és méretét - a szilárdsági és alakváltozási jellemzők megfelelő értékeinek biztosítása mellett - olyan pontosan állítsa elő, amely az azt követő forgácsoló megmunkálást minimálisra csökkenti vagy szükségtelenné teszi [1], így a környezetet szennyező nagy mennyiségü hütő-kenő folyadék felhasználása csökkenthető, kis környezetterhelésű megmunkálás valósítható meg. Ezen eljárások közé tartozik a gyémántszerszámos felületvasalás is, melynek alkalmazását, egyes beállítandó paramétereinek felületi érdességre gyakorolt hatását számos kutató kísérletileg is tanulmányozta.

Yu és Wang alumínium ötvözeten végzett kísérletük során a vasalási előtolás és sebesség mellett figyelembe vették a szerszámban lévő rugó merevségének hatását, valamint a vasalófej behatolási 
mélységét is. E két utóbbi jellemző esetében a nagyobb mértékủek alkalmazása okozott kedvezőbb eredményeket [2]. Hassan és Al-Bsharat ugyancsak nemfémes anyagon végzett kísérleti eredményei szerint a felületi érdesség javul a vasalás következtében, amennyiben növeljük az előtolás, erő, sebesség és járatszám értékét is, viszont csak egy bizonyos értékig, egy optimum-pontig, utána romlás tapasztalható [3]. Randjelovic és társai pedig elméleti szemszögből, numerikus szimuláció alkalmazásával közelítették meg az alumínium ötvözeten végzett vasalási eljárás vizsgálatát, melynek eredményei szerint azt állapították meg, hogy a felületi érdesség akkor csökkenthető a leghatékonyabban, ha a szerszám behatolási mélysége megközelíti az $\mathrm{R}_{\mathrm{p}}$ maximális érdességcsúcs magasságát.

Figyelembe véve a fent említett irodalmakat is, a számos felületi minőséget befolyásoló tényező közül, cikkünkben a vasalóerö átlagos felületi érdességre gyakorolt hatásának szimulációjával foglalkozunk.

\section{Felületkezelés vasalással}

A gyémántszerszámos vasalást nagy pontosságú, kis érdességü befejező műveletként alkalmazzák, mely megvalósítható egyetemes, valamint modernebb NC-CNC esztergagépeken is, utóbbi nagy elönye, hogy az egyes megmunkálási paraméterek számszerüen beállíthatóak. Az eljárás alkalmazása során megvalósuló érdesség-csökkenést, alakhelyesség-javulást és felkeményedést a megmunkálandó anyagnál jóval keményebb anyagú szerszám és a munkadarab felületének csúszási súrlódásakor végbemenő kölcsönhatás eredményezi [4-6], ahogy azt az 1. ábra is szemlélteti.
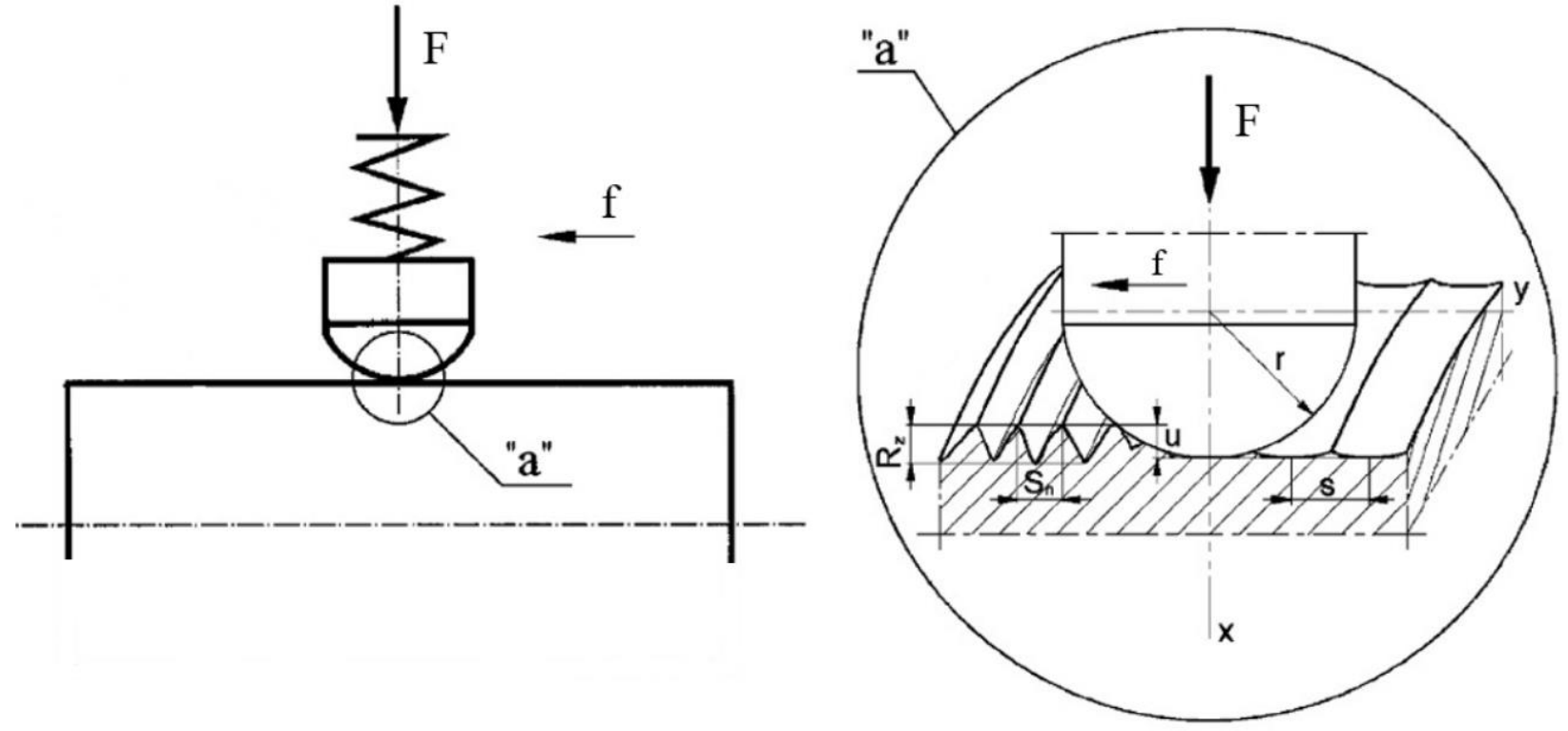

1. ábra $A$ vasalási müvelet sematikus ábrázolása [7].

F: vasalóerő; f: előtolás, u: szerszám behatolási mélysége, $S_{n}$ : megelőző megmunkálás okozta egyenetlenségek távolsága; r: szerszámsugár; Rz: megelőző megmunkálás okozta egyenetlenség-magasság $\left(\mathrm{R}_{\mathrm{z}}=\right.$

$\left.4 \mathrm{R}_{\mathrm{a}}\right)$

A gyakorlatban megvalósított vasalási kísérletet OPTIMUM gyártmányú OPTIturn L-típusú síkágyas CNC esztergagépen végeztük el $3,5 \mathrm{~mm}$ sugarú PCD anyagú szerszámmal az 1. táblázatban összefoglalt paraméterek szerint. 
1. táblázat. Vasalási paraméterek

\begin{tabular}{|c|c|c|}
\hline Technológiai paraméter & Érték & Mértékegység \\
\hline Vasalóerő $(\mathrm{F})$ & $10 / 20$ & $\mathrm{~N}$ \\
\hline Előtolás $(\mathrm{f})$ & 0,001 & $\mathrm{~mm} / \mathrm{ford}$ \\
\hline Sebesség $\left(\mathrm{v}_{\mathrm{c}}\right)$ & 15 & $\mathrm{~m} / \mathrm{min}$ \\
\hline
\end{tabular}

A munkadarab felületére merőleges vasalóerő beállítása a szerszámba épített rugó segítségével történik, rugóerő diagram alapján, mivel a lineáris rugókra érvényes Hook-törvény szerint a megnyúlás egyenesen arányos a terheléssel [8].

\section{Végeselem-módszer alkalmazása}

Vasalás során az egyes paraméterek változtatásával a felületi érdesség változásában elért eredmény vizsgálata rendkívül időigényes folyamat. Ez indokolta, hogy jelen tanulmányban a terhelőerő és a kapott felületi érdesség közötti kapcsolatot a virtuális térben tanulmányoztuk, így az idő és a költséghatékonyságot is szem elött tartva vizsgáltuk az összefüggést ezen paraméterek között.

A végeselemes szimulációk DEFORM szoftverben készültek, tengelyszimmetrikus probléma révén 2D-ben, síkalakváltozást feltételezve, így a szerszám munkadarabbal érintkező felülete egy félkörré egyszerüsödött. A valóságot legjobban megközelítő szimulációt céloztuk meg, ezért egy valós esztergált felület topográfiáját importáltuk a szoftverbe, melynek kezdeti felületi érdessége $1,478 \mu \mathrm{m}$ volt. A nagy keménységü PCD szerszám a vasalás során alakváltozáson nem esik át, tehát merevtestként definiáltuk. A munkadarab felületi érdességének csökkentése vasalás során képlékeny alakítással történik. Az érdességi csúcsokkal érintkező szerszám által kifejtett vasalóerő hatására kis képlékeny alakváltozások jöttek létre a munkadarab felszínén és annak közelében. A kis alakváltozások leírásához a kísérleti módon felvett folyásgörbe pontjait függvénnyel kell közelíteni a végeselemes térben. A szimulációkban a program által biztosított ,power law” összefüggést alkalmaztuk az alakváltozással változó folyási feszültség definiálására, melyet az alábbi képlet ír le:

ahol:

$$
\bar{\sigma}=c \bar{\varepsilon}^{n} \dot{\bar{\varepsilon}}^{m}+y,
$$

$\begin{array}{lll}\mathrm{c} & \text { anyagállandó, } & \mathrm{c}=121,228 \\ \bar{\varepsilon} & \text { képlékeny alakváltozás, } & \\ \dot{\bar{\varepsilon}} & \text { alakváltozási sebesség, } & \mathrm{n}=0,266076 \\ \mathrm{n} & \text { alakítási keményedési kitevő, } & \mathrm{m}=1,12487 \\ \mathrm{~m} & \text { alakváltozási sebesség kitevője, } & \mathrm{y}=50,0003 \mathrm{MPa} \\ \mathrm{y} & \text { kezdeti folyási feszültség } & \end{array}$

A szerszám a kifejtett erő mellett a munkadarab felületéhez viszonyított relatív elmozdulásával hoz létre alakváltozást a felületi rétegben. A szimulációban az elmozdulás sebessége megegyezett a valós sebességgel, a felületek közötti súrlódást pedig elhanyagoltuk. A vizsgálatok célja a felületek közötti szorítóerő változtatásával létrehozott felületi érdesség-változás vizsgálata volt. Ennek megfelelően $5 \ldots 20 \mathrm{~N}$ között 2,5 N osztással készítettünk el szimulációkat, melyek validálását 10 illetve $20 \mathrm{~N}$ szorítóerő esetére végeztük el. Ezen két erő hatására a vasalás kezdeti lépésében létrejövő alakváltozását szemléltet a 2. ábra. 


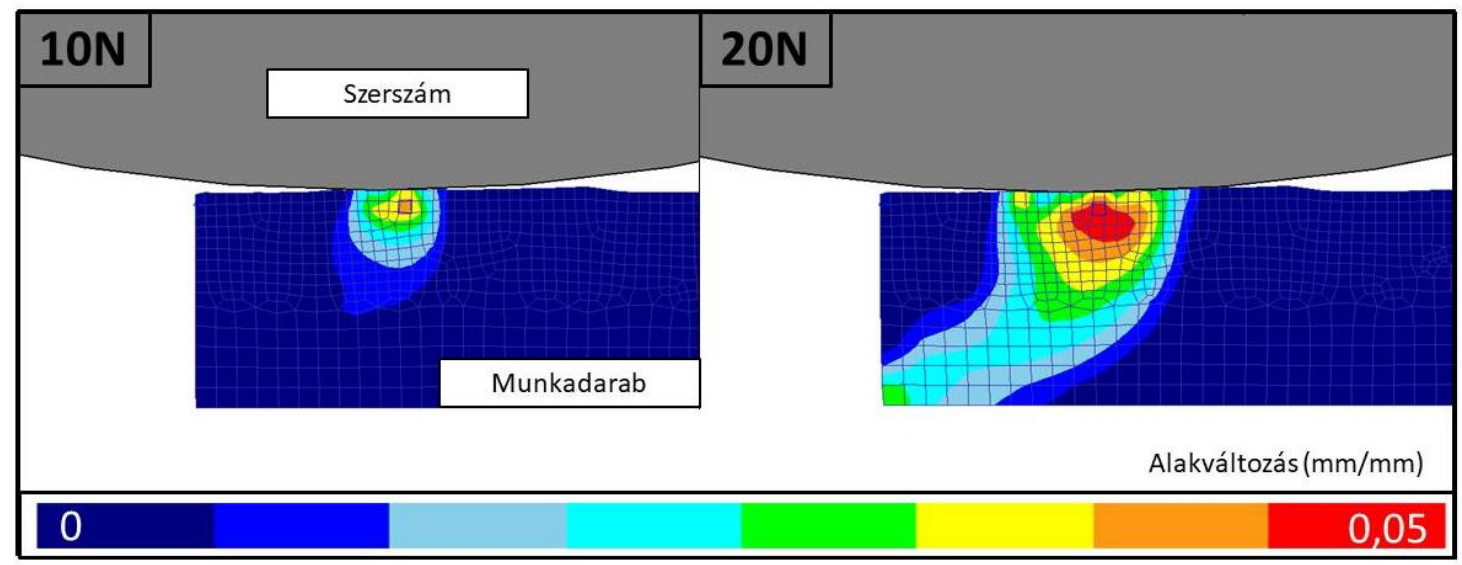

2. ábra A vasalóerö által létrehozott alakváltozás a megmunkálás elején.

\section{Eredmények}

A végeselemes modell futtatását követően kapott érdességre vonatkozó eredményeket a 2. táblázatban foglaljuk össze, mely $10 \mathrm{~N}$ és $20 \mathrm{~N}$ beállítása esetén hasonlítható össze a gyakorlatban megvalósított megmunkálással.

2. táblázat. Az átlagos felületi érdesség (Ra) számszerü értékei

\begin{tabular}{|c|c|c|c|c|c|c|c|}
\hline \multicolumn{7}{|c|}{$\mathrm{R}_{\mathrm{a}}[\mu \mathrm{m}]$} \\
\hline F [N] & $\mathbf{5}$ & $\mathbf{7 , 5}$ & $\mathbf{1 0}$ & $\mathbf{1 2 , 5}$ & $\mathbf{1 5}$ & $\mathbf{1 7 , 5}$ & $\mathbf{2 0}$ \\
\hline VEM & 1,177 & 0,0964 & 0,0819 & 0,0682 & 0,0574 & 0,0468 & 0,0388 \\
\hline Fizikai & & & 0,0965 & & & & 0,0367 \\
\hline
\end{tabular}

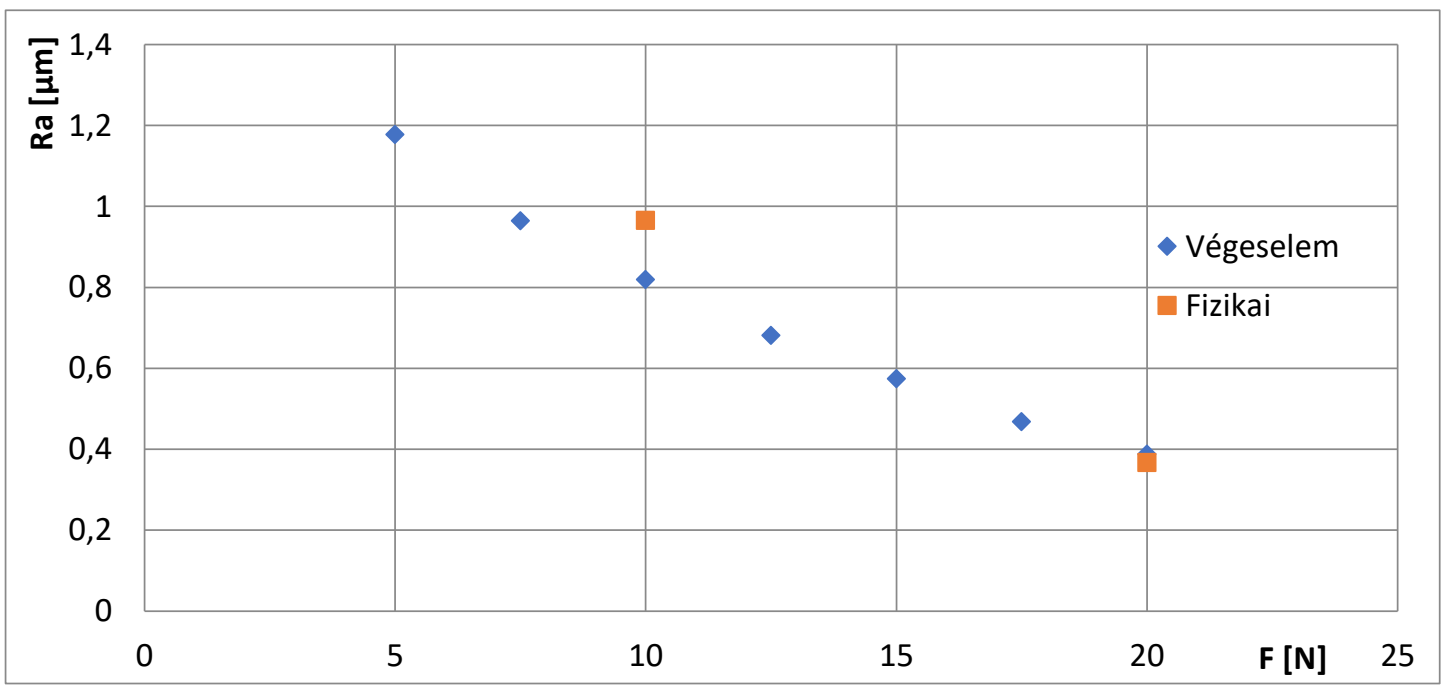

1. diagram $A$ vasalóerö felületi érdességre gyakorolt hatása. 


\section{5. Összefoglalás}

A cikk a gyémántszerszámos vasalási eljárás által okozott felületi érdesség-változás elemzésével és annak VEM szimulációjával foglalkozott, kiemelve a vasalóerő hatását. A szimulációs modell futtatása és a számszerủ eredmények kiértékelése alapján az alábbi megállapításokat tesszük:

- Gyengén ötvözött alumínium vasalási megmunkálása során az átlagos felületi érdesség mértéke egyenes arányosan csökken a vasalóerö növelésével, a további paraméterek szinten tartása mellett,

- A szimulációs modell megfelelő pontossággal egyezik a gyakorlatban megvalósított kísérlet mérési eredményeivel; az eltérés $10 \mathrm{~N}$ esetében $16 \%$, míg $20 \mathrm{~N}$ esetén csupán $6 \%$,

- Tehát a megalkotott modell hatékonyan felhasználható további vizsgálatok elvégzéséhez is

A megfogalmazottak alapján további elméleti kísérleti terveink közt szerepel a technológia kezdeti állapotainak vizsgálata különböző erők mellett.

\section{Köszönetnyilvánítás}

„A cikkben ismertetett kutató munka az EFOP-3.6.1-16-2016-00011 jelü „Fiatalodó és Megújuló Egyetem - Innovatív Tudásváros - a Miskolci Egyetem intelligens szakosodást szolgáló intézményi fejlesztése" projekt részeként - a Széchenyi 2020 keretében - az Európai Unió támogatásával, az Európai Szociális Alap társfinanszírozásával valósul meg".

\section{Irodalom}

[1] Tisza, M., Balogh, A., Schaffer, J.: Mechanikai technológiák, Miskolci Egyetem (2007), pp.: 73-74.

[2] Yu, X., Wang, L.: Effects of various parameters on the surface roughness of an aluminium alloy burnished with a spherical surfaced polycrystalline diamond, International Journal of Machine Tools \& Manufacture (1999), pp.: 459-469. https://doi.org/10.1016/S0890-6955(98)00033-9

[3] M. Hassan, A., Al-Bsharat, A.S.: Influence of Burnishing Process on Surface Roughness, Hardness, and Microstrucure of Some Non-Ferrous Materials, Wear 199 (1996), pp.: 1-8. https://doi.org/10.1016/0043-1648(95)06847-3

[4] Bálint, L., Gribovszki, L.: A gépgyártástechnológia alapjai, Miskolc (1975), pp.: 418-422.

[5] Luo, H., Liu, J., Wang, L., Zhong, Q.: The effect of burnishing parameters on burnishing force and surface microhardness, The International Journal of Advanced Manufacturing Technology (2005), pp.: 707-713. https://doi.org/10.1007/s00170-004-2412-0

[6] Akkurt, A.: Comparison of roller burnishing and other methods of finishing treatment of the surface of openings in parts from tool steel D3 for cold forming, Metal Science and Heat Treatment 53: 3 - 4 (2011), pp.: 145-150. https://doi.org/10.1007/s11041-011-9358-2

[7] Korzynski, M.: Modeling and experimental validation of the force-surface roughness relation for smoothing burnishing with a spherical tool, International Journal of Machine Tools \& Ma$\begin{array}{lllll}\text { nufacture } \quad \text { (Elsevier) } & 47 & \text { (2007), } & \text { 1956-1964. }\end{array}$ https://doi.org/10.1016/j.ijmachtools.2007.03.002

[8] Kozák, I., Szeidl, Gy.: Fejezetek a szilárdságtanból, Kézirat, Miskolc (2012), pp.: 204-208. 